\title{
The effect of a feed additive supplemented with porcine plasma protein on growth performance and selected biochemical indices of nursing piglets
}

\author{
Balázs Kósa, Katarína Bárdová, Lenka Lešková, Peter Reichel, Jaroslav Novotný, \\ Róbert Link, Miroslav Húska, Petronela Kyzeková, Arpád Csörgö \\ University of Veterinary Medicine and Pharmacy in Košice, \\ Clinic of Swine, Košice, Slovakia \\ Received October 23, 2018 \\ Accepted October 29, 2019
}

\begin{abstract}
The aim of this study was to evaluate the health state, performance, and selected serum biochemical indices in nursing piglets after supplementation of a feed additive containing porcine plasma protein in comparison to the control group fed a standard pre-starter feed mixture. The study was carried out in the conditions of industrial farming. Four sows of the Large White swine breed with their litters were included in the study. Piglets were homogenously distributed into control (22) and experimental (24) groups according to weight and sex. Piglets in both groups suckled their mothers' milk. In addition, piglets in the experimental group were also fed a feed supplemented by porcine plasma protein (5\%), starting on the third day post partum, whereas piglets in the control group were offered a standard pre-starter feed mixture. We recorded average daily weight gains calculated per the 27-day trial, and body weight at weaning. Clinical findings, mortality, and selected biochemical indices of protein (total immunoglobulins, total protein, albumin, creatinine, urea), and energy (glucose, total cholesterol, total lipids) metabolism were assessed as well. Results of the study showed a significant difference $(P<$ $0.01)$ in average daily weight gains in the experimental group compared to the control group ( 0.245 $\mathrm{kg}$ and $0.177 \mathrm{~kg}$, respectively). Addition of plasma protein in the experimental group also resulted in a significantly higher serum concentration of total immunoglobulins, total protein and creatinine, and a significantly lower concentration of urea and albumin in this group compared to the control group at weaning.
\end{abstract}

Protein source, immunity, digestibility, pigs

Efforts of pig breeders in intensive farming conditions are aimed at the most effective production of healthy and perspective animals. In terms of the analysis of critical control points (HACCP) in pig breeding, nutrition has been a key part of the chain. Production of viable and healthy piglets is a sine qua non for the subsequent successful performance of the herd. Optimal conditions must be ensured for optimal growth and ontogeny in the category of suckling piglets, and weaners as well. Side by side with standard feed mixtures, numerous other products have been used recently, such as porcine dried blood plasma, high quality pre-starters for piglets, organically bound microelements (iron, copper, manganese, zinc), porcine probiotics (Enterococcus faecium), plant extracts, toxin binders, enzyme products in combination with various vitamins (Figueroa et al. 2012) to reach the optimal performance. Swine diets must contain high levels of easily degradable nutrients due to high intensity of growth and reliance on sufficient enzymatic digestion; intensive growth is directly proportional to the intensity of proteosynthesis in the organism. Pigs are capable of using up to $35 \%$ of nitrogen in commercial feed mixtures (Bindas et al. 2013). Feed mixtures must contain balanced levels of proteins and other nutrients; at the same time, they must be used effectively so the producers can decrease the nutrient concentration in feed rations while maintaining their biological value for the animals. Although the order

Address for correspondence:

Katarína Bárdová

Clinic of Swine

University of Veterinary Medicine and Pharmacy in Košice

Komenského 73, Košice, Slovakia

Phone: +421907 778024

E-mail: katarina.bardova@uvlf.sk

http://actavet.vfu.cz/ 
can vary with different dietary ingredient mixtures, typically the first five limiting amino acids for most practical diets are lysine, threonine, methionine, tryptophan and valine (Goodband et al. 2014). However, formulating diets with high levels of synthetic amino acids to the optimal ratio for the first five limiting amino acids often resulted in poorer performance than diets with higher levels of intact protein source (Tokach et al. 2013). On the other hand, current standard diets that often meet the nutritional needs of pigs in terms of the most limited amino acids exceed other amino acids requirements, resulting in excessive nitrogen excretions. Degradation of these excess proteins could result in the production of obnoxious odours (Sutton et al. 1998). Grains contain relatively low levels of proto-plasmatic proteins (albumins and globulins) that are valuable in pig nutrition for their solubility, high digestibility and optimal amino acid composition (Bindas and Maskal'ová 2012). Storage proteins, such as prolamins and glutelins make up the biggest part of the protein content in grains. However, they contain only low levels of some amino acids, and are relatively poorly digestible causing nutritional deficiencies, especially in piglets; supplementation of amino acids is hereby needed in this case to meet the nutritional requirements (Kar et al. 2016). Use of dried plasma as a food additive in piglet nutrition increases the average daily feed intake by enhancing the palatability of feed mixtures; it subsequently improves average daily weight gains, and health state of animals (Van Dijk et al. 2001). It contains a considerable amount of amino acids and immunoglobulins that have a positive effect on gut microflora as well (Heres 2016). One of the key roles of plasma proteins is to stimulate the feed intake, which results in greatly improved weight gains. Increased feed intake in young pigs is known to reduce the incidence and severity of diarrhoea (Owusu-Asiedu et al. 2003). The efficacy of porcine plasma in animal feed seems to be related to an improved barrier function of the gut mucosa and the modulation of the mucosal immune response (PérezBosque et al. 2016).

Table 1. Composition of the pre-starter feed mixture (Complete compound feed for early weaning piglets OŠ 01, Tajba, a. s., Čaňa, Slovakia).

\begin{tabular}{lrr}
\hline Ingredient & \multicolumn{1}{c}{ Unit } & Amount \\
\hline $\mathrm{NS}$ & $\mathrm{g} \cdot \mathrm{kg}^{-1}$ & 200.0 \\
ME & $\mathrm{MJ} \cdot \mathrm{kg}^{-1}$ & 13.3 \\
Dietary fiber max. & $\mathrm{g} \cdot \mathrm{kg}^{-1}$ & 40.0 \\
Lysin & $\mathrm{g} \cdot \mathrm{kg}^{-1}$ & 14.0 \\
Methionine and cystine & $\mathrm{g} \cdot \mathrm{kg}^{-1}$ & 7.7 \\
Threonine & $\mathrm{g} \cdot \mathrm{kg}^{-1}$ & 9.1 \\
Calcium min. & $\mathrm{g} \cdot \mathrm{kg}^{-1}$ & 8.0 \\
Phosphorus & $\mathrm{g} \cdot \mathrm{kg}^{-1}$ & 6.7 \\
Sodium & $\mathrm{g} \cdot \mathrm{kg}^{-1}$ & 2.0 \\
Manganese & $\mathrm{mg} \cdot \mathrm{kg}^{-1}$ & 30.0 \\
Iron & $\mathrm{mg} \cdot \mathrm{kg}^{-1}$ & 125.0 \\
Copper & $\mathrm{mg} \cdot \mathrm{kg}^{-1}$ & 10.0 \\
Zinc & $\mathrm{mg} \cdot \mathrm{kg}^{-1}$ & 100.0 \\
Retinol & $\mathrm{IU} \cdot \mathrm{kg}^{-1}$ & 8000.0 \\
Calciferol & $\mathrm{IU} \cdot \mathrm{kg}^{-1}$ & 1000.0 \\
Tocopherol & $\mathrm{mg} \cdot \mathrm{kg}^{-1}$ & 20.0 \\
Riboflavin & $\mathrm{mg} \cdot \mathrm{kg}^{-1}$ & 3.0 \\
Cobalamin & $\mu \mathrm{g} \cdot \mathrm{kg}^{-1}$ & 20.0 \\
Choline & $\mathrm{mg} \cdot \mathrm{kg}^{-1}$ & 600.0 \\
\hline NS & \\
\hline
\end{tabular}

The aim of the study was to evaluate the health, production and selected biochemical indices in nursing piglets after application of a feed additive containing porcine plasma protein in comparison to an unsupplemented control group.

\section{Materials and Methods}

In terms of production parameters, the swine farm involved in the study belongs to the best breeding facilities for sows in Slovakia, yet one of the smallest ones, with around 50 breeding sows kept at the facility. Purebred sows of the Large White breed, as well as Landrace $\times$ Large White crossbreeds, and Pietrain $\times$ Yorkshire crossbreeds were kept at the farm. The number of piglets reaches 27.4 per sow per year. Average daily weight gains in the fattening period reach $0.9 \mathrm{~kg}$, with pre-weaning mortality of around $7 \%$. Nutritional requirements are supplied by complete mixed feed rations based on the Schauer technology, and managed by the Schaumann Company.

The study was carried out during the summer of 2016. Two sows with their litters $(n=24)$ as the control group and two other sows with their litters $(n=22)$ as the experimental group were used for the study. Selected sows manifested no clinical signs of impaired health state, or any reproductive failures (abortions or stillborn

NS - nitrogenous substances; ME - metabolizable energy 
Table 2. Composition of the experimental diet (SCHAUMA IMMUNO, Schaumann, Germany).

\begin{tabular}{|c|c|c|}
\hline Ingredient & Unit & Amount \\
\hline Crude protein & $\%$ & 18.8 \\
\hline Fat and oil & $\%$ & 9.2 \\
\hline Crude fibre & $\%$ & 2.7 \\
\hline Ash & $\%$ & 4.6 \\
\hline $\mathrm{ME}$ & $\mathrm{MJ} \cdot \mathrm{kg}^{-1}$ & 15.2 \\
\hline Calcium & $\%$ & 0.6 \\
\hline Phosphorus & $\%$ & 0.5 \\
\hline Sodium & $\%$ & 0.2 \\
\hline Lysine & $\%$ & 1.6 \\
\hline Methionine & $\%$ & 0.6 \\
\hline Retinol & $\mathrm{IU}$ & $24 \times 10^{3}$ \\
\hline Cholecalciferol & IU & $2.0 \times 10^{3}$ \\
\hline Tocopherol & $\mathrm{mg}$ & 200.0 \\
\hline Iron & $\mathrm{mg}$ & 250.0 \\
\hline Copper & $\mathrm{mg}$ & 160.0 \\
\hline Zinc & $\mathrm{mg}$ & 120.0 \\
\hline Manganese & $\mathrm{mg}$ & 64.0 \\
\hline Iodine & $\mathrm{mg}$ & 2.0 \\
\hline Selenium & $\mathrm{mg}$ & 0.5 \\
\hline Bonvital premix (Enterococcus faecium) & CFU & $1.0 \times 10^{9}$ \\
\hline Xylanase, glucanase, amylase, pectinase, benzoic acid & $\%$ & 0.5 \\
\hline Feed acidifiers (formic acid, lactic acid, fumaric acid) & $\%$ & 0.5 \\
\hline Feed preservants (butylhydroxytoluene, sorbic acid, calcium fumarate) & $\mathrm{mg}$ & 21.5 \\
\hline Propyl gallate & $\mathrm{mg}$ & 7.5 \\
\hline Ethoxyquin & $\mathrm{mg}$ & 3.3 \\
\hline Neohesperidin dihydrochalcone & $\mathrm{mg}$ & 1.5 \\
\hline Sodium saccharin & $\mathrm{mg}$ & 130.0 \\
\hline
\end{tabular}

ME - metabolizable energy

piglets). Piglets were marked with coloured ear tags for easier identification. All piglets were suckling their mothers' milk. Piglets in the experimental group were also offered the pre-starter feed mixture supplemented by plasma protein (5\%) (SCHAUMA IMMUNO, Schaumann, Germany) starting on the third day post partum, whereas piglets in the control group were offered the standard pre-starter feed mixture (Table 1) without any supplementation. The composition of the experimental feed mixture is shown in Table 2. All procedures involving animals followed the guidelines stated in the Guide for the Care and Use of Animals (protocol number 3323/16221/3) which was approved by the State Veterinary and Food Administration of the Slovak Republic and by the Ethics Committee of the University of Veterinary Medicine and Pharmacy in Košice, Slovakia. The animals were handled in a humane manner in accordance with the guidelines established by the relevant committee. All applicable international, national and institutional guidelines for the care and use of animals were followed.

Blood was drawn from sinus ophtalmicus for the analysis of selected biochemical indices in blood serum before the trial (after birth - day 0$)$, and at weaning $\left(28^{\text {th }}\right.$ day of age) as well. Piglets were weighed prior to blood sampling. Commercial test tubes without an anticoagulant were used for blood storage until further processing; blood serum was obtained by centrifugation at $867 \times g$ for $20 \mathrm{~min}$. Serum concentrations of immunoglobulins (TIg) and total lipids (TL) were detected by quantitative, spectrophotometric zinc sulphate turbidity assay (Specol 211, Carl-Zeiss Jena, Germany). Serum concentrations of total protein (TP), albumin (ALB), creatinine (CR), urea (U), glucose (GLU), and total cholesterol (TCH) were determined using an automatic spectrophotometric analyser Alize (Lisabio, France).

Statistical analysis of the results was carried out by assessment of mean values and standard deviations; the level of significance of detected differences between the experimental and control group was assessed using $t$-test, with post hoc analysis by Tukey's test in MS Excel 2016. 


\section{Results}

The average body weight (ABW; Table 3 ) at birth showed no significant difference between the control and experimental groups $(1.860 \mathrm{~kg}$, and $1.862 \mathrm{~kg}$, respectively), whereas at the weaning ABW in the control group $(7.147 \mathrm{~kg})$ showed a significant difference $(P<0.01)$ compared to the experimental group $(8.486 \mathrm{~kg})$. Differences in average daily weight gains (ADG), calculated per the 27-day trial in the experimental and control group $(0.245 \mathrm{~kg}$, and $0.177 \mathrm{~kg}$, respectively) were significant $(P<0.01)$ as well.

Concentrations of selected biochemical indices in blood serum of piglets are shown in Table 3. On day 0 they correspond to those of newborn piglets with no significant differences observed between the groups. Regarding the concentration of selected blood biochemistry indices, we found a significantly $(P<0.01)$ higher mean serum concentration of TP $\left(74.10 \mathrm{~g} \cdot \mathrm{l}^{-1}\right)$, TIg (25.39 UZST; units of zinc sulphate turbidity), and no significant value of CR $\left(101.54 \mu \mathrm{mol}^{\cdot l^{-1}}\right)$ at weaning in the experimental group when compared to the control group (56.05 $\left.\mathrm{g} \cdot \mathrm{l}^{-1} ; 16.06 \mathrm{UZST} ; 89.94 \mu \mathrm{mol} \cdot \mathrm{l}^{-1}\right)$. On the other hand, the opposite tendency with a significance of $P<0.01$ was observed in the mean serum concentration of $\mathrm{U}\left(3.09 \mathrm{mmol} \cdot \mathrm{l}^{-1} \mathrm{vs} 5.31 \mathrm{mmol} \cdot \mathrm{l}^{-1}\right)$ and ALB $\left(31.67 \mathrm{~g} \cdot \mathrm{l}^{-1} \mathrm{vs} 34.14 \mathrm{~g} \cdot \mathrm{l}^{-1}\right)$. There were no significant differences between groups in the concentrations of glucose, TL and TCH.

Table 3. Comparison of selected parameters of performance and serum biochemistry in the control and experimental group in piglets at birth and after weaning.

\begin{tabular}{|c|c|c|c|c|c|}
\hline \multirow[b]{2}{*}{ Indicator [unit] } & \multirow[b]{2}{*}{ Reference range } & \multicolumn{2}{|c|}{ Experimental group } & \multicolumn{2}{|c|}{ Control group } \\
\hline & & $\begin{array}{l}\text { Day 0 } \\
\mathrm{n}=22\end{array}$ & $\begin{array}{c}\text { Day } 28 \\
\mathrm{n}=22\end{array}$ & $\begin{array}{l}\text { Day 0 } \\
\mathrm{n}=24\end{array}$ & $\begin{array}{c}\text { Day } 28 \\
\mathrm{n}=19\end{array}$ \\
\hline$\overline{\mathrm{ABW}[\mathrm{kg}]}$ & & $1.862 \pm 0.274$ & $8.486^{*} \pm 0.513$ & $1.860 \pm 0.488$ & $7.147 \pm 0.971$ \\
\hline $\mathrm{ADG}[\mathrm{kg}]$ & & \multicolumn{2}{|c|}{$0.245^{*}$} & \multicolumn{2}{|c|}{0.177} \\
\hline TIg [UZST] & $20-35$ & $18.24 \pm 2.35$ & $25.39 * \pm 3.11$ & $15.32 \pm 10.38$ & $16.06 \pm 2.76$ \\
\hline $\mathrm{TP}\left[\mathrm{g} \cdot \mathrm{l}^{-1}\right]$ & $70-90$ & $50.00 \pm 3.19$ & $74.10^{*} \pm 8.38$ & $51.39 \pm 21.29$ & $56.05 \pm 8.63$ \\
\hline Albumin $\left[\mathrm{g} \cdot \mathrm{l}^{-1}\right]$ & $35-45$ & $18.31 \pm 2.25$ & $31.67 \pm 3.41$ & $16.26 \pm 5.27$ & $34.14 * \pm 5.87$ \\
\hline Creatinine $\left[\mu \mathrm{mol} \cdot \mathrm{l}^{-1}\right]$ & $141-239$ & $57.85 \pm 3.24$ & $101.54 \pm 11.13$ & $105.06^{*} \pm 56.64$ & $89.94 \pm 12.04$ \\
\hline Urea $\left[\mathrm{mmol} \cdot \mathrm{l}^{-1}\right]$ & $2.5-10.7$ & $4.42 \pm 1.55$ & $3.09 * \pm 0.81$ & $4.64 \pm 2.36$ & $5.31 \pm 1.01$ \\
\hline Glucose $\left[\mathrm{mmol} \cdot \mathrm{l}^{-1}\right]$ & $4.7-8.35$ & $6.68 \pm 0.87$ & $6.9 \pm 0.68$ & $7.31 \pm 1.37$ & $7.18 \pm 2.3$ \\
\hline $\operatorname{TL}\left[\mathrm{g} \cdot 1^{-1}\right]$ & $3.5-5.5$ & $5.56 \pm 0.59$ & $5.37 \pm 0.3$ & $5.03 \pm 0.68$ & $6.67 \pm 0.98$ \\
\hline $\mathrm{TCH}\left[\mathrm{mmol} \cdot \mathrm{l}^{-1}\right]$ & $2.6-3.9$ & $1.96 \pm 0.38$ & $3.59 \pm 0.5$ & $2.44 \pm 0.64$ & $4.29 \pm 0.66$ \\
\hline
\end{tabular}

Results are presented as mean \pm standard deviation, $*=P<0.01$

$\mathrm{n}$ - number of animals; ABW - average body weight; ADG - average daily gain; TIg - total immunoglobulins; TP -total protein; TL - total lipids; TCH - total cholesterol; UZST - units of zinc-sulphate test

\section{Discussion}

Numerous authors (Heres 2016; Grinstead et al. 2000; Lawrence et al. 2004) reported that feeding porcine blood plasma as a source of protein increases the feed intake, weight gains, and health performance of piglets when added to their diets in the pre-, and/or post-weaning period. On the other hand, several studies doubt that (Carlson and Veum 2000; Rigueira et al. 2013). The lack of consistent results among different papers may be related to factors such as environmental stress, immune challenge levels, and the complexity of the diets used in these studies (Pereira et al. 2012). The higher weight gain of animals supplemented with blood plasma may be affected by factors such as the age at weaning. In situations of normal challenge, diets supplemented with spray-dried plasma should be used in piglets not older than 35 days, because when used up to 35 days 
of age, the supplementation positively influences the average daily weight gain and the feed conversion ratio (Remus et al. 2013). The positive effects of functional feeds such as spray-dried blood plasma on pig performance are more dramatic when the animals are exposed to a higher level of immune challenge (Coffey and Cromwell 2001). The growth-promoting action of plasma protein added to feed mixtures could lie in the observed increase in feed intake due to increased palatability. Plasma proteins could have a direct effect on the intestines, leading to less intestinal diseases and, in turn, higher feed intake and daily gains as well (Perez-Bosque et al. 2016). The immunoglobulin and glycoprotein fractions may prevent attachment of pathogens and thus support functionality of the intestine (Van Dijk et al. 2001). This effect was also observed in different species. The glycoprotein glycans inhibited adhesion of bacteria to the intestine and protected colostrum-deprived calves against lethal doses of enterotoxigenic E. coli. There is some evidence that the feeding of large amounts of spray-dried plasma to weaned piglets offers protection against pathogenic E. coli (Nollet et al. 1999). In our study, we did not observe any health disorders in piglets of the control or experimental group that could have been related to this. Our results regarding performance (average daily weight gains and weight at weaning) were in accordance with a study in piglets fed the starter diet with spray-dried plasma protein (Pujols et al. 2016). Their body weight, average daily weight gain, and average daily feed intake improved during the initial 14 days after weaning, along with feed efficiency which improved during the initial 7 days after weaning. These responses were independent of the applied vaccination. In another study (Zhao et al. 2007), plasma protein and copper supplementation improved pig growth performance during the initial 10 days after weaning. The authors noticed a reduced crypt depth in the duodenum in piglets with only copper supplementation and a tendency for greater villous length with plasma supplementation. These modifications to non-medicated diets acted independently with regard to their impacts on the post-weaning performance and, therefore, could have additive effects. In contrast to these findings, in a study evaluating the effect of diets supplemented with plasma and/or yeast protein on the performance of piglets, no significant differences in intestinal morphology between piglets receiving the different diets were observed. The combination of plasma and yeast extract elevated daily weight gains, but did not affect the intestinal morphology of piglets from 7 to 63 days of age (pre- and post-weaning) (Rigueira et al. 2013). The reason for inconsistencies in the feed intake and subsequent weight gains independently from plasma supplementation might lie in different feeding rations and/or feeding schedule. It is probable that the change in consumption is dependent on the type and origin of ingredients. In this context, it is possible that the diet composition influenced the consumption due to the transit time of the diet in the intestinal tract (Black et al. 2009). Recent studies have mostly dealt with supplementation of porcine plasma to weaners (Grinstead et al. 2000; Torrallardona 2010). Less is known about the effect of plasma protein on nursing piglets, since the preventive measures are aimed at the most challenging periods, such as weaning time. Due to the post-weaning stress and changes in the diet, piglets are becoming more susceptible to pathogens as well as dietary imbalances.

As mentioned above, the analysis of biochemical indices in blood serum of piglets (Table 3) points to the positive effect of feeding dried porcine plasma to piglets during the nursing period on their immune function and nutrient absorption. Plasma urea nitrogen is used as an indicator of protein utilization efficiency because it increases when there is an imbalance of dietary amino acids (Coma et al. 1998).

Hence, the lower urea concentration in the experimental group suggests a positive effect of the plasma protein on the amino acid composition in the piglet feed ration compared to the control group. The significantly higher serum level of TP and TIg in the experimental group may be viewed as the result of improved gut function, as well as increased feed consumption/nutrient intake after supplementation of porcine dried plasma. This was in 
accordance with numerous studies assessing the effect of different feed additives on the production indices, immunity and blood biochemistry in weaned piglets ( $\mathrm{Li}$ et al. 2006; Zigger 2011; Xiong et al. 2015; Shenga and Nyachoti 2017). Furthermore, nutrient supplementation in nursing piglets shortly after birth has played an important role in the postnatal development of the immune system (Cunningham-Rundles et al. 2009).

In conclusion, we can assume that the addition of porcine plasma into pre-starter diets for nursing piglets had a positive effect on the production parameters such as average weight gains and weight at weaning by an improved and balanced nutrient intake, and also enhanced the immune functions represented by the serum level of TIg. The results of our study show that the porcine plasma protein can be a part of the strategy to support the health of piglets in critical phases of life, such as the nursing and weaning periods, thereby reducing the need to use of drugs.

\section{References}

Bindas L', Maskal'ová I 2012: Nutritional-biochemical evaluation of protein nutrition of weaning piglets (in Slovak). Proceedings of lectures X. Lazar Days of Nutrition and Veterinary Dietetics, September 2012, pp. 114-117

Bindas L', Maskal'ová I, Bujňák L 2013: The effect of dietary protein content on intermediary metabolism nitrogen excretion and performance of growing pigs (in Slovak). X. Kabrt Diet Days, Brno $25^{\text {th }}$ of April 2013, pp. 111-116

Black JL, Williams BA, Gidley MJ 2009: Metabolic regulation of feed intake in monogastric mammals. In: Torrallardona D, Roura E (Eds): Voluntary feed intake in pigs. Wageningen Academic Publishers, Netherlands, pp. 189-213

Carlson MS; Veum TL 2000: A comparison between feeding peptide and plasma protein on the nursery pig growth performance and intestinal health. Columbia, Missouri: University of Missouri, pp. 13-19

Coffey RD, Cromwell GL 2001: Use of spray-dried animal plasma in diets for weanling pigs. Pig News Inf 22: 39-48

Coma J, Carrion D, Zimmerman DR 1998: Use of plasma urea nitrogen as a rapid response criterion to determine the lysine requirement of pigs. J Anim Sci 73: 472-481

Cunningham-Rundles S, Lin H, Ho-Lin D, Dnistrian A, Cassileth BR, Perlman JM 2009: Role of nutrients in the development of neonatal immune response. Nutr Rev 67: 152-163

Figueroa J, Solà-Oriol D, Borda E, Sclafani A, Pérez JF 2012: Flavour preferences conditioned by protein solutions in post-weaning pigs. Physiol Behav 107: 309-316

Goodband B, Tokach M, Dritz S, Derouchey J, Woodworth J 2014: Practical starter pig amino acid requirements in relation to immunity, gut health and growth performance. J Anim Sci Biotechnol 5: 12

Grinstead GS, Goodband RD, Dritz SS, Tokach MD, Nelssen JL, Woodworth JC, Molitor M 2000: Effects of way protein products and spray-dried animal plasma on growth performance of weanling pigs. J Anim Sci 78: 647-57

Heres L 2016: The Role of plasma protein in young piglet feeding. Available at: www.pigprogress.net/Piglets/ Articles/2016/8/The-role-of-plasma-protein-in-young-piglet-feeding-2851293W. Accessed August 8, 2016

Kar SK, Jansman AJM, Boeren Kruijt SL, Smits MA 2016: Protein, peptide, amino acid composition and potential functional properties of existing and novel dietary protein sources for monogastrics. J Anim Sci 94: 30-39

Lawrence KR, Goodband RD, Tokach MD, Dritz SS, Nelssen JL, Derouchey JM 2004: Comparsion of wheat gluten and spray-dried animal plasma in diets for nursery pigs. J Anim Sci 82: 3004-3009

Li J, Li DF, Xing JJ, Cheng ZB, Lai CH 2006: Effects of beta-glucan extracted from Saccharomyces cerevisiae on growth performance, and immunological and somatotropic responses of pigs challenged with Escherichia coli lipopolysaccharide. J Anim Sci 84: 2374-2381

Nollet H, Deprez P, Van Driessche E, Muylle E 1999: Protection of just weaned pigs against infection with F18 Escherichia coli by non-immune plasma powder. Vet Microbiol 65 : $37-45$

Owusu-Asiedu A, Nyachoti CM, Marquardt RR 2003: Response of early-weaned pigs to an enterotoxigenic Escherichia coli (K88) challenge when fed diets containing spray-dried porcine plasma or pea protein isolate plus egg yolk antibody, zinc oxide, fumaric acid, or antibiotic. J Anim Sci 81: 1790-1798

Pereira CMC, Donzele JL, De Oliveira Silva FC, De Oliveira RFM, Kiefer C, Ferreira AS, Hannas MI, Brustolini PC 2012: Yeast extract with blood plasma in diets for piglets from 21 to 35 days of age. Rev Bras Zootec 41: 1676-1682

Pérez-Bosque A, Polo J, Torrallardona D 2016: Spray dried plasma as an alternative to antibiotics in piglet feeds, mode of action and biosafety. Porcine Health Manag 2: 16 
Pujols J, Segalés J, Polo J, Rodríguez C, Campbell J, Crenshaw J 2016: Influence of spray dried porcine plasma in starter diets associated with a conventional vaccination program on wean to finish performance. Porcine Health Manag 2: 4

Remus A, Andretta I, Kipper M, Lehnen CR, Klein CC, Lovatto PA, Hauschild L 2013: A meta-analytical study about the relation of blood plasma addition in diets for piglets in the post-weaning and productive performance variables. Livest Sci 155: 294-300

Rigueira LCM, Thomaz MC, Rigueira DCM, Pascoal LAF, Amorim AB, Budiño FEL 2013: Effect of plasma and/or yeast extract on performance and intestinal morphology of piglets from 7 to 63 days of age. Rev Bras Zootecn 42: 496-503

Shenga FL, Nyachoti M 2017: Using probiotics to improve swine gut health and nutrient utilization. Anim Nutr 3: $331-343$

Sutton AL, Kephart KB, Patterson JA, Kelly DT, Bogus E, Jones DD, Heber A, Nielsen J 1998: Manipulating nitrogen in pig diets to reduce manure nitrogen excretion and odors. Available at: http://www.ansc.purdue.edu/ swine/swineday/sday98/psd21-98.htm

Tokach M, DeRouchey J, Dritz S, Goodband B, Nelssen J 2013: Amino acid requirements of growing pigs. Available at: www.thepigsite.com/articles/4195/amino-acid-requirements-of-growing-pigs

Torrallardona D 2010: Spray dried animal plasma as an alternative to antibiotics in weanling pigs-A review. Asian-Aust J Anim Sci 23: 131-48

Van Dijk AJ, Everts H, Nabuurs MJA, Margry RJCF, Beynen AC 2001: Growth performance of weanling pigs fed spray-dried animal plasma: a review. Livest Prod Sci 68: 263-274

Xiong X, Yang H, Li B, Liu G, Huang R, Li F, Liao P, Zhang Y, Nyachoti CM, Deng D 2015: Dietary supplementation with yeast product improves intestinal function, and serum and ileal amino acid contents in weaned piglets. Livest Sci 171: 20-27

Zhao J, Harper AF, Estienne MJ, Webb KE Jr, McElroy AP, Denbow DM 2007: Growth performance and intestinal morphology responses in early weaned pigs to supplementation of antibiotic-free diets with an organic copper complex and spray-dried plasma protein in sanitary and nonsanitary environments. J Anim Sci 85: 1302-1310

Zigger D 2011: Practical use of blood plasma in piglet feeding. Available at: http://www.pigprogress.net/Home/ General/2011/3/Practical-use-of-blood-plasma-in-piglet-feeding-PP007802W/. Accessed March 31, 2011 